Informatika i sistemy upravleniya. - 2016. - No. 2(48). - P. 104-114.

Gribova V.V. (gribova@iacp.dvo.ru), Fedorischev L.A. (fleo1987@mail.ru)

Institute of Automation and Control Processes

\title{
CONTROL OF VIRTUAL SCENES
}

Here we described a conception of development and control of professional virtual environments using the software tool. The article presented control of a logical model in a virtual environment using new extended ontology and described a graphic contents control technology of 3D-scenes. It was also considered the process of interpretation of virtual environment taking into account its integrity checking.

Keywords. ontologies, control, virtual environments.

DOI: 10.22250/isu.2016.48.104-114

\section{For citation:}

Gribova V.V., Fedorischev L.A. CONTROL OF VIRTUAL SCENES // Informatika i sistemy upravleniya. - 2016. - No. 2(48). - P. 104-114. 